\title{
PERFORMANCE AUDIT: A CROSS-COUNTRY COMPARISON OF PRACTICES OF SELECTED SUPREME AUDIT INSTITUTIONS
}

\author{
Monika VASILIAUSKIENE் $\dot{1}^{1}$ Dalia DAUJOTAITÉ ${ }^{2}$ \\ ${ }^{1}$ Mykolas Romeris University, Vilnius, Lithuania \\ ${ }^{2}$ Faculty of Economics and Business, Mykolas Romeris University, Vilnius, Lithuania \\ E-mails: ${ }^{1}$ mon.vasiliauskiene@gmail.com; ${ }^{2}$ daujotaite@mruni.eu (corresponding author);
}

Received 08 April 2019; accepted 10 June 2019

\begin{abstract}
This study aims to present the conceptual framework of performance audits impact that support our investigation of the process of selection performance audit topics at Supreme audit institutions (SAIs) level. The results of the study include the technique for choosing performance audit topics used by the Lithuanian SAI and the SAI of the Netherlands. The data were gathered using case studies and semi-structured in-depth interviews with the field experts. The results of the study demonstrated a range and the complexity of the arguments underlying the selection of the topic for performance audits: there are no mandatory requirements or standards governing the process; therefore, every SAI chooses its own path. Each SAI applies specific performance audit topics selection methods determined by their original long-term practical experience. Selecting right topics for performance audit is a task of crucial importance for each SAI. Gathering information about all areas and making a decision where to perform an audit is an important part of strategic research efforts. Data collection is a lengthy process that takes place throughout the year. Each SAI has a framework for strategic and annual planning that has clearly set deadlines, uses a transparent qualified and/or quantified approach to ranking risks/audit proposals, and is based on the criteria relating to materiality, topicality, feasibility and added value.
\end{abstract}

Keywords: supreme audit institutions, performance audit, audit topics, impact, case study.

JEL Classification: M42, M48.

\section{Introduction}

Performance audit is a government review process that covers a broad range of activities, which can be approached in many ways (Gomes 2001, Kim et al. 2017). An institutional approach to performance audit is a useful way to show an empirical angle of a performance audit. Such institutional analysis of performance audit led to a conclusion that it is a much more complex approach of review than any conventional forms of audit.

Performance audit is different from any traditional types of audit, such as financial audits intended to assess the accuracy of financial accounts, or compliance audits carried out to check the conformity of financial and operational controls and activities with the relevant applicable laws, directives, procedures or standards. The choice where to perform financial audit is usually fairly straightforward, or in certain cases such audit may be mandatory, as financial audits focus on public sector financial accounts; in the meantime, areas for selecting the topics for performance audit are much more complex.

There are no mandatory requirements or standards for choosing to carry out a performance audit, therefore every SAI has to make it is own decision. Education, property and finance, justice, health and social security, culture - these are the main, but just selected areas of the public sector that can be covered by performance audits.

Choosing an inappropriate topic for a performance audit means that even if the audit itself was conducted properly, it

\footnotetext{
Copyright $\odot 2019$ The Authors. Published by VGTU Press.

This is an Open Access article distributed under the terms of the Creative Commons Attribution License (http://creativecommons.org/licenses/by/4.0/), which permits unrestricted use, distribution, and reproduction in any medium, provided the original author and source are credited..
} 
has no added value or even can be detrimental to the society (Simonaityte 2018). Gathering information about areas where to perform audit is an area of strategic research at the SAI level, which in the same way as the objects of SAI level performance audit has not been dealt with by researchers to any more comprehensive extent.

The study aims to present the conceptual framework of performance audits impact that support our investigation of the process of selection of performance audit topics at Supreme audit institutions (SAIs) level. The Lithuanian SAI and the SAI of the Netherlands were used as a sample for the purpose of the present study. The decision was taken having considered a number of factors. Firstly, the SAI of the Netherlands is an institution with experience of several centuries, while Lithuanian SAI is a relatively young public authority that can apply the best practice of foreign States in its practical operations. Secondly, the Netherlands SAI operates a well-developed performance audit methodology and techniques and plays a significant role in the performance audit field on the global level.

Any research is carried out based on specific hypothesis supported by the data that are collected and analysed for the purpose. The data were gathered using case studies and semi-structured in-depth interviews with the field experts. The expert pool included management-level officials directly involved in taking strategic decisions in entities.

The article consists of four parts. Part 1 presents the conceptual framework of performance audit impact and contains a theoretical analysis of choosing performance audit topic, also presents the hypothesis formulated for the purpose of the study. Part 2 presents an overview of the research methods used in this study. Part 3 discusses of the results of the research exercise. Part 4 presents the discussion and conclusions of the research.

\section{Theoretical analyses and hypothesis development}

\section{Impact of performance audit}

This section research aim is to present the conceptual framework of the performance audit impact, and the changes caused by the impact at a range of levels, such as micro, meso and/or macro level. Most authors (Reichborn-Kjennerud and Johnsen 2015, Reichborn-Kjennerud 2014, ReichbornKjennerud and Vabo 2017, Pina et al. 2016, Brans et al. 2017) studying the subject analyzed the impact of audit through the level of recognition of the reports (to what extent the reports were considered relevant the society, the stakeholders and the government), and to what extent the recommendations produced as a result of a performance audit were implemented at the auditee. However, a number of recent year's studies (Reichborn-Kjennerud 2014, Raudla et al. 2015, Brans et al. 2017, Carrington 2017, Johnsen et al. 2019) investigated the impact of audit through the experience of the entities being audited. In this respect Johnsen et al. (2019) proposed a concept of four-dimensional (usefulness, holding to account, change and improvement) performance audit impact. Essentially, performance audits are perceived useful when they provide new knowledge. This new information may be used for holding someone in account and (or) making changes which may or may not result in improvements. The findings of this study revealed that significant determinants of positive performance audit impact were better communication of performance audits to society via media, higher legitimacy of SAIs' as well as high quality audit reports and less "rigidity" in performance audit. A empirical study carried out by Reichborn-Kjennerud (2014) showed that the auditees considered the performance audit useful only provided their opinion was taken into account in the course of the audit, if the entities' representatives were assured that the audit was completed in a quality manner, any positive changes are observable in the institution after the implementation of the recommendations, the audit report is a means for dissemination of best practice, and in general, audit process is an incentive to learn.

Both of the above-mentioned research areas corroborated the importance of performance audit process, therefore selection of the audit topic, determination of the relevant criteria, as well as the study methods used undoubtedly affect the impact produced by performance audit. For the purpose of the study the authors propose the following hypothesis:

H1: Depending on the performance audit topic, relevant changes can be at the micro, meso or macro level.

The assessment of the impact produced by performance audit is one of the important subjects in a research discourse. Although researchers hold very diversified opinions regarding the impact of performance audit, the very discussion about the impact is a proof of the existence of such impact. In the opinion of many authors in the area the impact of performance audit is of instrumental nature, i.e. it is a linear process (Put and Van Loocke 2011, Pollitt 1999, Funkhouser 2011, Lonsdale 1999a, 2011b). It has been universally recognised that any study carried out adds new knowledge, and new knowledge triggers changes in policies. Lonsdale (1999a, 2011b) has noted that the impact of audit may be both direct and indirect (see Figure 1). The impact of a performance audit is perceived as the effect that the entity being audited experiences with respect to its operations and the different practices. The impact of performance audit cannot be straightforwardly described as limited to the changes proposed in the subsequent recommendations (Mul and Pollitt 1999, Put 2011, Johnsen and ReichbornKjennerud 2015). An audit research in its entirety affects the entity being inspected, therefore the effect is manifested in both negative and positive observations by the auditor 


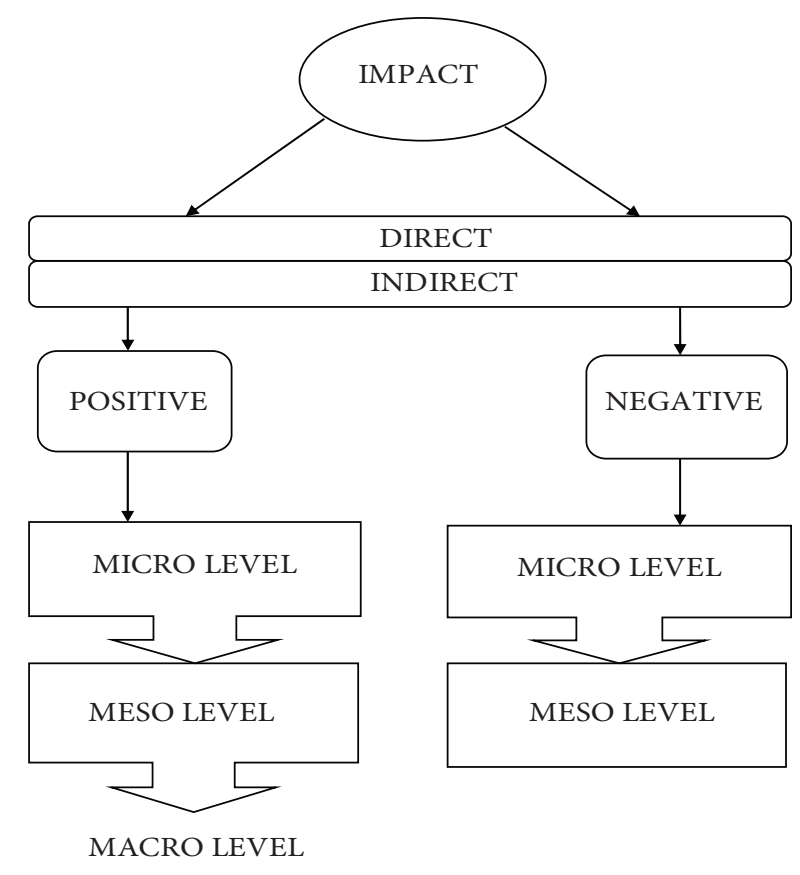

Figure 1. The impact of a performance audit

(see Figure 1). As has been mentioned by quite a number of researchers, the direct and the indirect impact of audit can potentially be positive, as well as negative.

The positive impact of performance audit affected by micro, meso and macro factors (Put and Van Loocke 2011) trigger respective changes. Since the process in its essence is linear, the changes at the micro level can lead to changes at the meso level, and further causes changes at the macro level. Depending on the subject to be audited, the purpose of a performance audit is to cause changes at the meso and macro levels (see Figure 1).

Changes at the micro level are affected by a range of micro-level factors, such as audit process, communication with the auditee, the audit report, etc. The principal development at the micro level is the completed study and the new knowledge obtained as a result. The aim is to ensure that any changes that took place at the micro-level lead to respective changes at the meso-level.

Meso-level factors are in essence the relations between the SAI and the entity subject to audit. Among such factors can be the reputation of the SAI, the position of the entity being audited, its ability to accommodate new information, the relevance of the topic for the entity being audited and the society. Depending on the topic of a performance audit, and the objectives pursued, the main objective of the performance audit can be the relevant changes at the mesolevel. According to Pollitt 1999, Funkhouser 2011, Lonsdale 1999a, 1999b, 2011a, the effects of a performance audit at the meso-level include:

- changes at the SAI;

- changes in the operations and the management of entities;
- organisational learning;

- spread of the best practices;

- inclusion of the public;

- enhancement of knowledge.

Changes at the SAI level. Enhanced attention on the part of the public authorities to efficiency, effectiveness and the quality of services creates an "echo effect" at the SAI level.

Changes in the operations and the management of entities. The information presented in the performance audit report may introduce certain changes in the operations and the management of institutions and organisations, e.g. recommendations on the possible improvement of operations, achieve some savings, introduce different safeguards, etc.

Organisational learning. Opportunities to receive new information about the relevant activities, problem areas, also possibilities to improve efficiency - the entirety of the factors promotes critical thinking and organisational training on the ways to apply in their activities any new approach or information.

Spread of best practices. Any new experience may circulate between the divisions of a single organisation, or units, or an organisation may choose to share the best practice with its partners or colleagues.

Inclusion of the public and enhancement of knowledge. A public discussion of the problem, as well as a dialogue among policy-makers, the society and experts promote enhanced engagement of the public in the problem resolution process, enhances the understanding of the problem areas among the policy-makers, in addition to offering an opportunity for voicing different views; the participation of experts brings about more rationality and expert knowledge. The meso-level impact of the performance audit is more of an organisational or institutional nature.

The macro-level impact is manifested as changes in the public administration programme, areas of policy (Pollitt 1999, Funkhouser 2011, Lonsdale 1999a, 2011a, 2011b). The studies carried out in the area of performance audit are increasingly often becoming a basis for legislators in providing supporting information or recommendations for relevant subsequent actions of the government. Any macro-level factors are essentially the decision-making process in the policy area, relations between the Government, the Parliament and the related interest groups. Without a doubt, changes in the macro-level are the most significant impact of performance audit.

Negative impact of performance audit may manifest itself at the micro or meso-levels, i.e. from the organisational and institutional viewpoint. The impact at the micro-level is related to the reliability of the information provided in the auditor's report. In the opinion of Put and Van Loocke (2011), the sources potentially causing undesirable effect may include:

- the entity being audited creates a sham or a demonstrative picture; 
- lack of flexibility, when an audit only highlights the formal procedures.

At the meso-level Put and Van Loocke (2011), Lonsdale (2011b), Leeuw (1996) and Haferkorn (2018) Masiulevicius and Lakis (2018) have identified the following possible undesirable impacts:

- tunnel vision when the auditor excessively highlights a single aspect without having regard to the context;

- improvement of a single segment by inflicting harm to the entire activity;

- where through the cooperation with the auditor the auditee suffers a loss that outweighs the benefits obtained from the audit procedure;

- at times the commitment of people to work and motivation are diminished once the auditor identifies even a minor deficiency;

- communication risks between the auditor and the audited entity (audit findings that are rarely presented at the right time; disagreements on the facts of an audit findings etc.).

For the reasons referred to earlier a task of primary importance for the auditor is to efficiently manage the negative impact of a performance audit and seek to mitigate it.

The present study demonstrates a range of views on the possible impact of performance audit carried out by the SAIs. According to Lonsdale (1999a), Put and Van Loocke (2011), the impact of performance audit affected by micro, meso and macro factors trigger respective positive or negative impacts and changes. Therefore, the impact of a performance audit upon changes is inseparable from the selection of the right subject. For identifying the factors affecting the process, the author has formulated the second hypothesis:

$\mathrm{H}_{2}$ : The selection of the topic for a performance audit is determined by internal and external SAI-related factors.

That constitutes one of the main hypotheses of the present paper and that has been designed to study the relevance of the problem on the basis of a selected SAI sample.

\section{Choosing a performance audit topic}

An analysis of the practice pursued by SAIs demonstrated that auditors use a comprehensive and systematic process to select the topics that best meet their mandate and will have the greatest impact on a relevant level. Thus, the primary objective of a performance audit is to provide the Parliament with independent assurance and opinion about the economy, efficiency and effectiveness of public sectorrelated activities. Another objective is to encourage the auditees to improve their performance and achieve greater benefit from the use of the resources available to them.

Selection of performance audit topics is a part of the planning process (INTOSAI 2016). Planning of performance audits is a process consisting of three stages: determination of the external environment within which public entities operate; determination of public sector entities' business risks and selection of performance audit areas. Determination of the external environment, i.e. an understanding of the general economic conditions; social and technological developments; the priorities, goals, objectives and programmes of the Government, the legal and political framework; the accounting and auditing framework and environmental requirements and the determination of public sector entities' business risks. Business risk (Tarasova et al. 2018) arises from significant conditions, events, circumstances, actions or indicators that could adversely affect the entity's ability to achieve its objectives and execute its strategies, or through the setting of inappropriate objectives and strategies (for example, additional costs, inadequate human and financial resources, IT infrastructure and etc.). SAIs topics usually are selected on the basis of their relevance and mandate as indicated by the following criteria: SAI policy and strategy; risk and materiality assessment; government wide issues; modernizing the Government; result oriented activities and programmes; audit areas of interest to the Parliament, the media and the general public; auditability; deliverability, timelines, feasibility, visibility, value added and potential impact.

According to Simonaityte (2018), Summa (1999), Lonsdale (2011a, 2011b), Put and Turksema (2011), Lee et al. (2016) focusing upon the activities of the SAIs in the Western Europe, the significance of selection of the topics of performance audit, and the factors underlying the decision on specific topics have shown that the selection of the topics is affected by both external and internal factors.

External factors - are the factors present in the environment in which the SAI operates, and directly affecting the choice of the topic of a performance audit. With reference to the findings of the authors of the present paper as described above the following factors may be identified:

- Institutional position - the position of the SAI within the public administration structure, and the mandate granted to it.

- Nature and the impact of the public administration system. The SAI is a public entity which for carrying out its activities is using public funds, therefore, in the same manner as the entities being audited must be subject to the criteria of cost-effectiveness and efficiency.

- Relevance of the topic, its economic significance and the impact upon the society. The relevance of the topic may be a political discussion ongoing at a specific time, or some specific activities in the public sector that has attracted the significant attention of the public. Quite often the selection of the topic is determined by its financial significance; however, there might be a case that any activity that has a significant impact upon the society is not very important from 
the financial viewpoint and as such may remain unnoticed. In order to avoid such mistakes, it is crucially important to assess the validity and reasonableness of each of the following factors.

- Availability of information. Availability of information is a factor that to a larger extent limits the selection of the topic; the topic may be very relevant, financially significant, have a significant impact upon the society, comply with the mandate granted to the SAI, but the absence of the relevant data or reliable information from the area may significantly restrict the work of performance auditors.

- Political taboo. A performance auditor cannot evaluate the results of certain political decisions. The most conspicuous example of such a situation is a redistribution of funds for national security.

Internal factors are related to organisational and operational processes that also directly affect the selection of the audit topic, and include the SAI mission, strategic plans and objectives, procedures for selecting audit topics, monitoring procedures, risk analysis process, cost-benefit analysis with respect to the entity being audited, professional judgement of the auditor, the information from previous audits, available resources and their allocation.

Thus, potential topics for performance audit come from discussions with stakeholders, including the public service, and may concern the government, changes to government sectors etc. The potential topics include areas of great significance to the general population and supported by the taxpayers (education, health care, environment), risk-prone areas (IT systems), and many more of complex "wicked" problems that require sustainable efforts to ensure that they are properly managed. Time also plays an important role. The timing of an audit can affect the relevance and value of the audit findings and recommendations. An immediate issue that receives a lot of public attention in one month may change drastically by the next one, so it is worth considering whether to go ahead with an audit when circumstances might render the findings obsolete by the time the report is released. For that reason, SAIs must choose topics with much care and an eye to systemic long-term added value. The results of audits ideally must help public agencies avoid major issues to start with- not just attempt to right what has already gone wrong.

Bringselius and Lemne (2017) state that the professional qualifications of the Auditor General (education, professional experience) has a significant influence on the performance audit conducted by a SAI. The education of the Auditor General reveals what knowledge (law, political science, economics, etc.) is important for the institution and the state. The academic degree may reflect upon the management requirements for research, performance audit reports, etc. Previous work experience displays whether the head of the institution is a specialist who will be involved in the research or a generalist with a wider spectrum of knowledge, subsequently keeping distance from the direct research process and giving more freedom to his auditors.

\section{Research method}

The study covered by the present paper is designed as a comparative case study between the SAIs in two countries: the Lithuania and the Netherlands. The choice of the countries was determined by several facts. Firstly, as it was mention previously, the difference in the experience accumulated by the two SAIs. The SAI of the Netherlands, i.e. Algemene Rekenkamer was established in 1814, and in 1976 a new Governmental Resolution was passed to extend the authority of the SAI authorising it also to carry out performance audits (Algemene Rekenkamer 2017). The Lithuanian SAI, i.e. Valstybės kontrolè was established back in 1919, and the first performance audit was carried out in 2002, after the new version of the law on National Audit Office (2002) came into effect. Secondly, distinction in SAIs governance. Algemene Rekenkamer is a collegial organization where the final decision on which audits are being carried out is made by the board. On the other hand, Valstybès kontrole is a Westminster model institution, headed by the Auditor General. Thirdly, in their strategies both SAIs focus more on systemic issues and seek long-term impact of performance audit as well as emphasize the quality of the performance audit process. Algemene Rekenkamer plays a significant role in the performance audit field on the global level, whereas Valstybès kontrole, despite of a relatively short experience, is broad-minded and an ambitious institution. They are consequently interesting cases to study in order to understand the strategic choices by the SAIs. The study carried out for the purpose of the present paper was looking for links between the existing practice and the relevant theoretical assumptions.

According to Yin (2009), Gerring (2004), a case study method enables a close examination of the data within a specific context. In most cases a case study method selects a very limited number of objects for the examination. Case studies, in their true essence, explore and investigate contemporary real-life phenomenon through detailed contextual analysis of a limited number of events or conditions, and their relationships. Yin (2009) defines the case study research method "as an empirical inquiry that investigates a contemporary phenomenon within its real-life context; when the boundaries between phenomenon and context are not clearly evident; and in which multiple sources of evidence are used."

Another method employed for the purpose of the present study was semi-structured in-depth interviews with a 
number of experts in the field. Such interviews were carried out with a view to identifying the principal factors affecting the areas and issues of the study and summarising the results. The purpose of the semi-structured in-depth interviews with the experts was to identify the policy built by the SAI with respect to the topics, study methods and the criteria selection approaches. The semi-structured interviews were conducted using four groups of questions. The first group consisted of questions of general nature - mostly concerning the aims of performance audits in that relation seeking to identify which of such aims are the most important, etc. The remaining three groups of questions were designed to identify the strategies applied in each SAI concerning the methods for selecting the topics, criteria and research methods for performance audit. The exercise included an attempt to define the existing situation, the experts were inquired regarding the difficulties they encountered and any areas that in their opinion could be improved. Not all questions from the questionnaire were asked, however, in the course of the interview exercise some additional questions were instead included in the questionnaire.

\section{Data analyses}

The experts selected for this study are management-level officials from both the Lithuanian and the Dutch SAIs with extensive knowledge of performance audit processes, also directly involved in the strategic decision-making processes. Each SAI was represented by two experts.
In this section, in order to test hypothesis, public documents of SAIs and data collected from semi-structured interviews have analyzed.

Valstybès kontrolè - VK. According to our research for selecting an audit topic the VK uses two information collection sources: the environment and the proposal. The environment is any source of information selected by the auditor. Proposals are received by way of inquiring certain selected institutions and organisations. The auditors have compiled the lists of the organisations to which such inquiries are communicated. The list is compiled by Ministries, the Government, non-governmental organisations, associations and other organisations that act as potential providers of information. Figure 2 shows the result of data collection analysis. Such proposals may also be submitted by natural or legal persons by filling in a special form available on the internet website of the VK.

The collected information is further analysed at the Department level, and together with the Director of the Department each risk is assessed according to the following eight criteria: annual priorities of the SAI; relation to the strategic documents of the state; budget appropriations/ income; relevance of the problem; indicators; long term (in) tangible assets; professional assessment; external proposals. Each criterion is further subdivided into sub-criteria the aggregated assessment of which produces a final score of a respective criterion. The criteria differ in terms of their weight - some are more important than others are. Having

\begin{tabular}{|c|c|c|c|}
\hline $\begin{array}{l}\text { Preparation of } \\
\text { preliminary audit } \\
\text { proposals }\end{array}$ & $\begin{array}{l}\text { Discussion of } \\
\text { preliminary audit } \\
\text { proposals }\end{array}$ & $\begin{array}{l}\text { Discussion of audit } \\
\text { proposals }\end{array}$ & $\begin{array}{l}\text { Preparation of } \\
\text { draft audit } \\
\text { programme }\end{array}$ \\
\hline $\begin{array}{l}\text { at audit department } \\
\text { level: brainstorming } \\
\text { based on } \\
\text { information } \\
\text { collected, ranking } \\
\text { done in the public } \\
\text { sector } \\
\text { (May) }\end{array}$ & $\begin{array}{l}\text { between heads of audit } \\
\text { departments and the } \\
\text { auditor general, } \\
\text { deputies of auditors } \\
\text { general, and audit } \\
\text { development } \\
\text { department } \\
\text { (June) }\end{array}$ & $\begin{array}{l}\text { between heads of } \\
\text { audit departments and } \\
\text { the auditor general, } \\
\text { deputies of auditors } \\
\text { general, and audit } \\
\text { development } \\
\text { (October) }\end{array}$ & $\begin{array}{l}\text { including } \\
\text { presentation to the } \\
\text { VK Council }\end{array}$ \\
\hline
\end{tabular}

\begin{tabular}{|c|c|c|c|c|}
\hline $\begin{array}{l}\text { Stakeholder } \\
\text { survey } \\
\text { addressed to the } \\
\text { President's office, } \\
\text { government office, } \\
\text { ministries, other } \\
\text { state institutions } \\
\text { and NGOs. } \\
\text { (May) }\end{array}$ & $\begin{array}{l}\text { Survey } \\
\text { addressed to } \\
\text { Parliamentary } \\
\text { comities }\end{array}$ & $\begin{array}{l}\text { Seminar } \\
\text { discussion } \\
\text { with } \\
\text { academics } \\
\text { and other } \\
\text { experts about } \\
\text { priorities for } \\
\text { the next year. } \\
\text { (October) }\end{array}$ & $\begin{array}{l}\text { Presentation } \\
\text { of draft audit } \\
\text { programme } \\
\text { to the } \\
\text { Committee on } \\
\text { Audit } \\
\text { (December) }\end{array}$ & $\begin{array}{l}\text { Publication of } \\
\text { year audit } \\
\text { programme } \\
\text { and delivery to } \\
\text { Parliament, the } \\
\text { President and } \\
\text { Prime Minister } \\
\text { and etc. } \\
\text { (January) }\end{array}$ \\
\hline
\end{tabular}

Data collection (all year round), including citizens complains and proposals via the VK website/ internet

Figure 2. Preparation of performance audit programme 
assessed the relevant risks the Departments formulate the topics that are further submitted for assessment to the VK. The topics are assessed by the management of the VK, and Heads of the Departments, if necessary, engaging specialists in individual areas. The topics are assessed with respect to the same eight criteria that were mentioned earlier, in addition to the assessment by the manager. The assessment by the manager is a criterion based on the professional and managerial expertise of the manager, i.e. a strategic judgement criterion. The procedure is followed by compiling a preliminary list of possible audit topics having regard to the availability of financial, human, time and other resources. The list is subsequently reviewed and approved as part of the annual Action plan. The annual Action plan also provides for the audits commissioned by the State. The list of performance audits with indicated scheduled time for performing topics is publicly available on the VK internet website.

As shown in Figure 2 (ECA 2014, National Audit Office of Lithuania 2002, 2013,2016), data collection is a process that takes place throughout the year. The VK has a solid framework for annual planning with specifically set clear deadlines. Our research showed that the VK uses a transparent and quantified approach to ranking the risks/audit proposals. The approach is based on a range of criteria relating to materiality, topicality, feasibility and added value. As part of implementing best practice relevant stakeholders are consulted at several stages throughout the process.

Proposals regarding the tasks to be fulfilled as part of an audit are submitted by audit departments taking into account any input from the relevant stakeholders. Given this predominantly bottom-up approach, the audit proposals may reflect rather the existing resource allocation than the overall strategic priorities. The bottom-up approach also entails a risk of a silo effect, whereby insufficient priority is given to crosscutting issues and appropriate audit proposals are less likely to emerge as a result. The situation could be improved by using strategic priority areas.

Algemene Rekenkamer - AR. Structurally the AR consists of four Directorates of which three engage in audits. The functions carried out by three audit Directorates include monitoring of the environment, analysis of the information collected by means of audits and the relevant risks. Each directorate is assigned a certain number of clusters, e.g. Directorate I is responsible for the cluster of general affairs, finance, internal affairs, supply of national housing cluster, and the cluster of the supreme State councils and institutions. The AR implements total five programmes: reporting studies, public finances, revenues, efficiency, health care and social security, for the implementation of which responsibility lies with the Directorates The monitoring of the environment and the market analysis at the AR are carried out at two levels: the cluster-level risk analysis, and the system-level risk analysis according to the programmes as referred to above. The process for selection of topics at the AR consists of three information flows:

- Request by the Parliament. Although with respect to the AR no requests of the Parliament are necessary, this is the most important source for the selection of audit topics. At a request of the Parliament the auditors draw up a strategic document for an audit topic that is further submitted for evaluation by the management and the Heads of the Directorates of the AR.

- Strategy. Strategic planning is the second most important flow of information relevant for the selection of audit topics. The auditors perform the environment monitoring and the risk analysis based on six criteria: complexity of the problem, the authority of the SAI, financial materiality, expert opinion, professional expertise and relevance for the society. On the basis of the analysis the AR strategy singles out the key areas of focus for performance audits. The AR strategy for 2016-2020 defined four areas as a primary focus for performance audits (Algemene Rekenkamer 2016).

- Environment monitoring. The third information flow derives from the analysis of the audits previously completed, environment monitoring and risk analysis. The information obtained by way of an audit is analysed on the basis of the following nine criteria: relevance of the current; conformity with strategy, the authority of the SAI; complexity of the problem; financial magnitude; professional experience; importance for the public; expert opinion; appropriate timing.

Firstly, the AR criteria are not scored in points as is in the case of the $\mathrm{VK}$, and the decision regarding the indicators used or the amount of information that shows the problem or the risk inherent to a specific area depends on the judgement of the auditor.

Secondly, the AR does not publish its annual Action plans.

Thirdly, as claimed by the experts, previously the cluster level performance audit was exercised more frequently, however, it was noted that by focusing upon micro-level problems auditors often miss broader or system-scope issues. On the system level the risks are assessed following the established programmes. Audits include analysis of broadscale problematic system-based issues. Such two levels risk analysis is performed by auditors together with the Heads of the Directorates. The process of the analysis serves as a basis for formulating the topics for performance audit. The risk analysis criteria are the same as used of the purpose of the monitoring, except that the analysis is carried out with respect of a specific cluster or a programme. No scores are assigned to the criteria, performance audit themes are not rated, and the decision in that respect is taken by the auditor in discussion with the management. The consensus-based 
decision passed in the course of the discussion represents the application of the so-called Dutch polder model.

The polder model stands for consensus-oriented consultation between the social partners who agree concerning a decision despite their differences. According to De Vries (2014), this polder model decision-making strategy is up till now actively applied in political, economic and social areas. At that stage the auditor must persuade the Heads of the Directorates concerning the importance of the theme proposed thereby, in other words, "sell" his theme to the management. The AR does not publish any list of scheduled audits on its website.

Nevertheless, in the opinion of the experts, the weakness of the mechanism for the selection of audit topics is related to an insufficient flexibility of the organization, its inability to respond to a risk factor that was missed during the analysis, or a suddenly emerging situation that may have significant consequences.

A system-based problem resolution approach when selecting audit topics has become an essential part of SAIs. The so-called "horizontal" audits that serve as a measure for identifying issues in the public sector of systemic nature, rather than those of a single project or an institution; the issues in focus in this case are, for instance, budget management, public investment management, etc. It is apparent that the purpose of audit is not only to identify systemic deficiencies, but also to propose the solutions for their decisions; the impact is then sought by implementing the recommendations of the audit.

On the other hand, it should be noted that the AR does not classify performance audits into any individual groups based on specific criteria. According to the experts the principal purpose of a performance audit is its impact, therefore, in terms of the impact audits may be of the following types:

- long-lasting in-depth audits;

- short-term overview audits;

- other audits that fall in between the two categories;

- short-term, medium-term and long-term specific area audits.

Audits of the first three types are to a larger degree associated with the system level analysis. Audits of the latter type are more related to the cluster-level analysis.

In experts' opinion, there are several factors potentially restricting the selection of the audit topics:

- absence of quality or reliable data;

- politically sensitive themes;

- ill-timing;

- confidential information (e.g. medical records of patients);

- a study carried out by another assessment institution;

Thus, the mechanism for choosing the topic for performance audits is quite complex. Each SAI applies specific performance audit topics selection methods determined by their original long-term practical experience. SAIs use a comprehensive and systematic process to select the topics that best meet they mandate and will have the greatest impact. The selection of the topics for performance audits is shaped by a number of external and internal factors at the SAI level.

\section{Discussion and conclusions}

The present study demonstrates a range of views on the possible impact of performance audit carried out by SAIs. The major findings of the literature review showed that the factors influencing the impact of performance audits can be defined as factors at the micro, meso and macro level. Figure 1 in the present paper summarizes all factors that might influence the impact of performance audits conducted by SAIs. The impact of performance audit affected by micro, meso and macro factors trigger respective positive or negative impacts and changes. Review of numerous research papers and number of empirical studies carried out by Put and Van Loocke (2011), Pollitt (1999), Funkhouser (2011), Lonsdale (1999a, 1999b, 2011b), Johnsen (2019) et al. have produced comparable results concluding that changes (obtained new knowledge) at the micro level can lead to changes at the meso level (organisational or institutional nature), and further cause changes at the macro level (public administration programme, Government programmes, etc.)

The findings of various empirical studies carried out in the area reveal performance audit topic selection strategies including the techniques used by the Lithuanian and Dutch SAIs, demonstrate the range and complexity of arguments underlying the selection of topics for performance audit. There are no mandatory requirements or standards governing the selection of performance audit topics, as every SAI chooses its own path. A study in the issue showed that each SAI applies specific performance audit topic selection methods determined by its original long-term practi$\mathrm{cal}$ experience. The topic selection process is nonetheless constantly changing as new challenges of public administration consistently reveal limitations of such methods such as a lack of flexibility or a risk of the silo effect where important systematic issues might be missed due to lack of communication.

The findings further indicate that the impact that a performance audit can produce is complex and is affected by several factors. The present study indicated that usefulness and quality of a performance audit are the main factors affecting a perceived audit impact. The topic selection process presumes a sort of performance audit that will be conducted in each specific case. In this respect the Duch SAI identifies four types of performance audits: long-lasting in-depth audits; short-term overview audits; other audits that fall in 
between the two categories; short-term, medium-term and long-term specific area audits.

Analysing impact of performance audit the topic selection process was identified as one of the key factors which may cause positive as well as negative effect of a performance audit and consequently facilitate or obstruct any further changes. These aspects have been scarcely considered in research literature therefore the coverage of the subject in the present paper can be considered a valuable contribution to the studies in the area.

The analyses in the area comparing Lithuania and the Netherlands showed that the mechanism for choosing the topic for performance audits are quite complex: there are no mandatory requirements or standards governing the issue. Each SAI applies specific performance audit topics selection methods determined by its original long-term practical experience. SAIs use a comprehensive and systematic process to select the topics that best meet their mandate and will produce the most tangible impact. Gathering information about all areas and deciding where to perform an audit is an important part of each SAIs' strategic planning. The selection of the performance audit topics is a structured and targeted process that encompasses different levels and stages. The factors underlying the decision on specific topics is affected by both external and internal factors. Data collection is a continuous process taking place throughout a year. The SAIs have a framework for annual planning with clearly established deadlines, use a transparent and quantified approach to ranking risks/audit proposals that is based on criteria relating to materiality, topicality, feasibility and added value.

SAIs' topics usually are selected on the basis of their relevance and mandate as indicated by the following criteria: the policy and strategy of the SAI; risk and materiality assessment; government-wide issues; modernizing the Government; result oriented activities and programmes; audit areas of interest to the Parliament, the media and the general public; auditability; deliverability, timelines, feasibility, visibility, value added and potential impact. The findings of such exercise support the second hypothesis formulated by the authors of the present paper. The weakness of the mechanism for the selection of audit topics stems from an insufficient flexibility of organizations, their inability to respond to a risk factor that was missed during the analysis, or a suddenly emerging situation that may have significant consequences.

These results of the present study showed that performance audits carried out by SAIs' performance audits largely have positive impacts on public administration, provided the audit topic selection process followed a systemic problem-decision making pattern. The system audits potentially identify a range of problems not only at a single project or an institution level, but also at a systemic public sector level, while the impact is sought by promoting the implementation of the recommendations provided as a result of a performance audit.

\section{References}

Algemene Rekenkamer (2017) Trust based on understanding Netherlands Court of Audit Strategy for 2016-2020 https:// english.rekenkamer.nl/latest/news/2016/03/24/strategy2016-2020-insight-as-a-basis-for-confidence

Algemene Rekenkamer (2017) About the Algemene Rekenkamer http://www.rekenkamer.nl/Over_de_Algemene_Rekenkamer

Brans $\mathrm{M}$ et al. (2017) Impact of performance audit on the Administration: a Belgian study (2005-2010) Managerial Auditing Journal 32 (3): 251-275. https://doi.org/10.1108/ MAJ-04-2016-1368

Bringselius L, Lemne M (2017) What qualifications does good state audit require? Statsvetenskaplig Tidskrift 119 (1): 111-136.

Carrington T (2017) Consulting or holding to account?: The Swedish National Audit Office as an agent of change in public administration. Statsvetenskaplig Tidskrift 119 (1): 91-109.

De Vries J (2014) The Netherlands and the Polder model questioning the Polder model concept. In: BMGN - Low Countries Historical Review. Royal Netherlands Historical Society 129 (1): 99-111. https://doi.org/10.18352/bmgn-lchr.9449

Funkhouser M (2011) Accountability, performance and performance auditing: reconciling the view of scholars and auditors. In: Ling T Lonsdale J, Wilkins P (Ed). Performance auditing contributing to accountability in democratic government. Cheltenham, Northampton: Edward Elgar Publishing, 175208. https://doi.org/10.4337/9780857931801.00017

Gerring J (2004) What is a case study and what is it good for? The American Political Science Review 98 (2): 341-354. https:// doi.org/10.1017/S0003055404001182

Gomes MB (2001) Performance audit argument: a public management policy analysis about supreme audit institutions role. Control by Evaluacióndel DesempeñoGubernamental. Caracas.

Haferkorn P (2018) Risk communication from an audit team to its client. In: Bieder C and Bourrier M (Ed). Risk communication for the future. Springer, Cham, 139-153. https://doi. org/10.1007/978-3-319-74098-0_10

INTOSAI (2016) Appendix to ISSAI 3100 - Building a Performance Audit Function http://www.issai.org/data/files/3B/76/ AF/B3/92909510F72E9F859B59F9C2/ISSAI\%203100_Appendix_ingl_s.pdf

INTOSAI (2016) ISSAI 3000 - Standard for Performance Auditing. - INTOSAI Professional Standards Committee.

INTOSAI (2016) ISSAI 3100 - Guidelines on Central Concepts for Performance Auditing. INTOSAI Professional Standards Committee.

INTOSAI (2013) ISSAI 300 - Fundamental Principles of Performance Auditing. Adopted by XXI INCOSAI 2013, Beijing, China.

Johnsen A et al. (2019) Supreme audit institutions in a high-impact context: A comparative analysis of performance audit in four Nordic countries. Financial Accountability \& Management 35 (2), May 2019: 158-181. https://doi.org/10.1111/ faam. 12188 
Kim et al. (2017) The strategic options of supreme audit institutions: the case of four Nordic Countries. Financial Accountability \& Management 33 (2), May 2017: 146-170. https:// doi.org/10.1111/faam.12118

Law on Internal Control and Internal Audit of the Republic of Lithuania No. IX-1253. Valid Consolidated Version as of 01/01/2013 created in 2002 December the 10th https://esmas. lrs.lt/portal/legalAct/lt/TAD/TAIS.197703/dYSRaZnPfI

Law on State Audit Performance of the Republic of Lithuania in 1995 May the 30th No. I-907 consolidated version as of 04/02/2015 https://www.etar.lt/portal/lt/legalAct/ TAR.61BB05227699/vHVdNOBKRh

Lee et al. (2016) A comprehensive survey of government auditors' self-efficacy and professional development for improving audit quality. SpringerPlus 5: 1263. https://doi.org/10.1186/ s40064-016-2903-0

Leeuw FL (1996) Performance auditing, new public management and performance improvement: questions and answers. Accounting, Auditing \& Accountability Journal 9 (2): 92-102. https://doi.org/10.1108/09513579610116385

Lonsdale J (1999a) Impacts. In: Girre X, Lonsdale J, Mul R, Pollitt C, Summa H, Waerness M (Ed). Performance or compliance? Performance Audit and Public Management in Five Countries. Oxford, New York, 171-193.

Lonsdale J (1999b) Methods. In: Girre X, Lonsdale J, Mul R, Pollitt C, Summa H, Waerness M (Ed). Performance or compliance? Performance audit and public management in five countries. Oxford, New York, 125-148.

Lonsdale J (2011a) Introduction. In: Ling T, Lonsdale J, Wilkins P (Ed). Performance auditing. Contributing to accountability in democratic government. Cheltenham, Northampton: Edward Elgar Publishing, 1-21.

Lonsdale J (2011b) The right tools for the job? Methods, choice and context. In Ling T, Lonsdale J, Wilkins P (Ed). Performance auditing. Contributing to accountability in democratic government. Cheltenham, Northampton: Edward Elgar Publishing, 95-117.

Masiulevicius A, Lakis V (2018) Differentiation of performance materiality in audit based on business needs. Entrepreneurship and Sustainability 6 (1): 115-124. http://doi.org/10.9770/ jesi.2018.6.1(9)

Mul R, Pollitt C (1999) Criteria. In: Girre X, Lonsdale J, Mul R, Pollitt C, Summa H, Waerness M (Ed) Performance or compliance? Performance audit and public management in five countries. Oxford, New York, 79-104. https://doi.org/10.1093/ acprof:oso/9780198296003.003.0006

National Audit Office of Lithuania (2002) Public audit requirements auditor. In: General's order no. V-26 created in 2002 February the 21st http://www.vkontrole.lt/page.aspx?id=32

National Audit Office of Lithuania (2013) Code of service ethics of the auditor general of the Republic of Lithuania. In: The Auditor General's order no. V-116 created on 2013 June the 7th http://www.vkontrole.lt/page.aspx?id=388

National Audit Office of Lithuania (2016) The State's performance audit action plan 2016 https://www.vkontrole.lt/dokumentai/ veikla/Valstybes_kontroles_2016_m._veiklos_planas.pdf

National Audit Office of Lithuania (2017) The strategic plan of action of the National Audit Office of Lithuania for the years 2017-2019. In: The Auditor General's law No. V-32 created in 2016 January the 26th https://www.vkontrole.lt/ page.aspx?id=1695

National Audit Office of Lithuania (2017) Regulations http://www. vkontrole.lt/page.aspx?id=6

Nederlandse Grondwet (2017) http://www.denederlandsegrondwet.nl/9353000/1/j9vvihlf299q0sr/vgrncyzdduxq

Pina V et al. (2016) Are performance audits useful? A Comparison of EU Practices. Administration \& Society. SAGE Publications, 1-32.

Pollit C (1999) The management - audit interface. In: Girre X, Lonsdale J, Mul R, Pollitt C, Summa H, Waerness M (Ed). Performance or compliance? Performance audit and public management in five countries. Oxford, New York, 56-65. https://doi.org/10.1093/acprof:oso/9780198296003.003.0004

Pollit C (1999) The changing context. In: Girre X, Lonsdale J, Mul R, Pollitt C, Summa H, Waerness M (Ed). Performance or compliance? Performance audit and public management in five countries. Oxford, New York, 30-55. https://doi. org/10.1093/acprof:oso/9780198296003.003.0003

Put V (2011) Norms used: some strategic considerations from the Netherlands and the UK. In Ling T, Lonsdale J, Wilkins $\mathrm{P}$ (Ed). Performance auditing. contributing to accountability in democratic government. Cheltenham, Northampton: Edward Elgar Publishing, 75-94. https://doi. org/10.4337/9780857931801.00010

Put V, Turksema R (2011) Selection of topics. In: Ling T, Lonsdale J, Wilkins P (Ed). Performance auditing. Contributing to accountability in democratic government. Cheltenham, Northampton: Edward Elgar Publishing, 51-74. https://doi. org/10.4337/9780857931801.00009

Put V, Van Loocke E (2011) The impact of performance audit: a review of the existing evidence. In: Ling T, Lonsdale J, Wilkins P (Ed). Performance auditing. Contributing to accountability in democratic government. Cheltenham, Northampton: Edward Elgar Publishing, 175-208.

Raudla R et al. (2015) The impact of performance audit on public sector organizations: the case of Estonia. Public Organization Review 16: 217-233. https://doi.org/10.1007/ s11115-015-0308-0

Reichborn-Kjennerud K (2014) Performance audit and the importance of the public debate. Evaluation - SAGE Publications 20 (3): 368-385. https://doi.org/10.1177/1356389014539869

Reichborn-Kjennerud K, Johnsen A (2015) Performance audits and supreme audit institutions' impact on public administration: the case of the office of the auditor general in Norway. Administration \& Society - SAGE Publications, 1-25. https:// doi.org/10.1177/0095399715623315

Reichborn-Kjennerud K, Vabo SI (2017) Performance audit as a contributor to change and improvement in public administration. Evaluation - SAGE Publications 23 (1): 6-23. https:// doi.org/10.1177/1356389016683871

Simonaityte Z (2018) Choosing a performance or compliance audit topic at supreme audit institution. International scientific conference, February 8-9 2018. Abstracts of reports - Vilnius university, 31 . 
Strategy of Supreme Audit Institution 2016-2020 Auditor General's of the Republic of Lithuania order no. V-59 created on 2016 March 22 https://www.vkontrole.lt/dokumentai/2016_strategija/Auksciausiosios_audito_institucijos_strategija_2016-2020.pdf

Summa H (1999) The subjects of study. In: Girre X, Lonsdale J, Mul R, Pollitt C, Summa H, Waerness M (Ed). Performance or compliance? Performance audit and public management in five countries. Oxford, New York, 66-78. https://doi. org/10.1093/acprof:oso/9780198296003.003.0005

Tarasova VI et al. (2018) Methodological provision for the assessment of audit risk during the audit of tax reporting. Enterpreneurship and Sustainability Issues 6 (1): 371-397. https://doi.org/10.9770/jesi.2018.6.1(23))

The European Court of Auditors (ECA) (2014) Peer review of the National Audit Office of Lithuania, 2014.

Yin RK (2009) case study research: design and methods (4th ed).

SAGE Publications. 